Kennesaw State University

DigitalCommons@Kennesaw State University

Faculty Publications

5-1995

\title{
The Analysis of Genetically and Physiologically Complex Traits Using Ceratopteris: A Case Study of NaCl-Tolerant Mutants
}

Thomas R. Warne

University of Tennessee - Knoxville

Dale L. Vogelien

Kennesaw State University, dvogelie@kennesaw.edu

Leslie G. Hickok

University of Tennessee - Knoxville

Follow this and additional works at: https://digitalcommons.kennesaw.edu/facpubs

Part of the Botany Commons, Plant Biology Commons, and the Plant Breeding and Genetics Commons

\section{Recommended Citation}

Warne TR, Vogelien DL, Hickok LG. 1995. The analysis of genetically and physiologically complex traits using ceratopteris - a casestudy of nacl-tolerant mutants. Int J Plant Sci 156(3):374-84.

This Article is brought to you for free and open access by DigitalCommons@Kennesaw State University. It has been accepted for inclusion in Faculty Publications by an authorized administrator of DigitalCommons@Kennesaw State University. For more information, please contact

digitalcommons@kennesaw.edu. 
The Analysis of Genetically and Physiologically Complex Traits Using Ceratopteris: A Case Study of NaCl-Tolerant Mutants

Author(s): Thomas R. Warne, Dale L. Vogelien and Leslie G. Hickok

Source: International Journal of Plant Sciences, Vol. 156, No. 3 (May, 1995), pp. 374-384

Published by: The University of Chicago Press

Stable URL: http://www.jstor.org/stable/2474873

Accessed: 29-06-2016 13:44 UTC

Your use of the JSTOR archive indicates your acceptance of the Terms \& Conditions of Use, available at

http://about.jstor.org/terms

JSTOR is a not-for-profit service that helps scholars, researchers, and students discover, use, and build upon a wide range of content in a trusted digital archive. We use information technology and tools to increase productivity and facilitate new forms of scholarship. For more information about JSTOR, please contact support@jstor.org.

The University of Chicago Press is collaborating with JSTOR to digitize, preserve and extend access to International Journal of Plant Sciences 


\title{
THE ANALYSIS OF GENETICALIY AND PHYSIOLOGICALLY COMPLEX TRAITS USING CERATOPTERIS: A CASE STUDY OF NaCl-TOLERANT MUTANTS
}

\author{
THOMAS R. WARNE, ${ }^{1, *}$ DALE L. VOGELIEN, $†$ AND LESLIE G. HICKOK* \\ *Department of Botany, University of Tennessee, Knoxville, Tennessee 37996; and †Department of Biology and Physics, \\ Kennesaw State College, Marietta, Georgia 30061
}

\begin{abstract}
Genetic and physiological complexities associated with salt tolerance in plants have limited progress in the analysis of specific factors responsible for the salt-tolerant phenotype. We have used the homosporous fern Ceratopteris richardii as a model plant to investigate the physiological basis of salinity tolerance by selecting single gene mutants that confer tolerance in the gametophyte generation. The unique genetic system of homosporous ferns permits the generation of mutants in a genetic background nearly isogenic to the wildtype, such that comparative studies with the wildtype can identify specific physiological responses associated with salt tolerance. One of these mutations, stl2, confers a high level of tolerance to $\mathrm{Na}^{+}\left(\mathrm{I}_{50} \approx 175 \mathrm{mM} \mathrm{NaCl}\right)$ and generates a complex suite of related phenotypes. For example, in addition to $\mathrm{Na}^{+}$tolerance, stl2 exhibits tolerance to $\mathrm{Mg}^{2+}$ salts, sensitivity to supplemented $\mathrm{K}^{+}$, higher $\mathrm{K}^{+}$dependent efflux of $\mathrm{K}^{+}$, altered responses to $\mathrm{Ca}^{2+}$ supplementation and moderate tolerance to osmotic stresses. Based upon its physiological attributes, we have proposed that the mechanism of action for this mutation involves an enhanced influx of $\mathrm{K}^{+}$and higher selectivity for $\mathrm{K}^{+}$over $\mathrm{Na}^{+}$in a $\mathrm{K}^{+}$channel. The direct and indirect consequences of this alteration can account for $\mathrm{NaCl}$ tolerance and the other phenotypes evident in stl2. The complex set of phenotypic responses from such a single gene mutation illustrates the potential for even more extreme pleiotropy in multigenic salt-tolerant strains.
\end{abstract}

\section{Introduction}

Model systems can be especially useful when employed to examine traits that are difficult to study in other organisms. Some traits, such as salinity tolerance, have evolved independently in a number of plant taxa and exhibit extremes of genetical and physiological complexity. Consequently, progress has been limited in the identification of specific genetic factors associated with tolerance, as well as the net contributions of these factors and their interactions. To further our understanding of the genetic basis of salinity tolerance, we have successfully used Ceratopteris to select single gene mutations that confer tolerance. A large number of stable salt-tolerant mutant lines are now available, and, as they are characterized genetically and physiologically, we are examining their expression both singly and in combination. By this approach, we are attempting to identify synergistic and additive combinations of genetic modifications that result in significant levels of tolerance.

\section{Physiological complexity of salt tolerance}

The study of the mechanisms of salt tolerance in plants not only addresses the important agricultural problem of crop response to soil salinization but also may provide insight into the fundamental processes of ion transport, accumulation, and regulation across the plasma membrane as well as information on the biophysical events that affect a plant exposed to salt stress. Although

\footnotetext{
'Author for correspondence and reprints.
}

Manuscript received September 1994; revised manuscript received December 1994. several other ions, e.g., $\mathrm{SO}_{4}{ }^{2-}$ and $\mathrm{Mg}^{2+}$, may contribute to soil salinity stress, the toxic effects of $\mathrm{Na}^{+}$and $\mathrm{Cl}^{-}$are considered important (Flowers and Yeo 1986) and serve predominantly as model ions in experimental studies. Despite numerous studies of plant responses to salt stress, little is known about the specific genetic basis and associated physiological mechanisms that can confer tolerance to salt (Cheeseman 1988; Dracup 1991). Many basic physiological attributes have been suggested as important components of a salt-tolerant phenotype, including direct modification of the influx and/or efflux of ions such as $\mathrm{K}^{+}$and $\mathrm{Na}^{+}$across the plasma membrane and tonoplast (Jeschke 1984; Flowers and Yeo 1986; Yang et al. 1990b); synthesis of compatible osmotica such as proline, other amino acids, soluble carbohydrates, and glycine betaines (Jones and Storey 1981; Sumaryati et al. 1992); and modifications of membrane composition (Kuiper 1984, 1985; Hirayama and Mihara 1987; Peeler et al. 1989; Blits and Gallagher 1990). These physiological mechanisms and numerous others that are presumed to confer some level of salinity tolerance have been reviewed extensively (Rains 1972, 1987; Flowers et al. 1977; Epstein et al. 1980; Greenway and Munns 1980; Yeo 1983; Läuchli and Epstein 1984; Flowers and Yeo 1986; Rhodes et al. 1986; Epstein and Rains 1987; Cheeseman 1988; Munns 1993). In general, halophytes compartmentalize both $\mathrm{Na}^{+}$and $\mathrm{Cl}^{-}$into the vacuole and regulate ion transport at both the plasma membrane and tonoplast (Flowers et al. 1977, 1990; Flowers 1985; Flowers and Yeo 1986). The osmotic imbalance of the cytoplasm relative to the vacuole and the external environment may be adjusted by the accumulation of compatible 
organic solutes, such as proline, betaine, or sugars in the cytoplasm (Flowers et al. 1977; Greenway and Munns 1980; Motah et al. 1987; Binzel et al. 1988). Some halophytes have differential responses to salinity levels, e.g., Spergularia marina "includes" $\mathrm{Na}^{+}$at low levels and "excludes" it at high levels (Cheeseman and Wilkens 1986). Other adaptations associated with some halophytes include transport of $\mathrm{Na}^{+}$to specialized glands or bladders and succulence (Flowers et al. 1977). Some nonhalophytes, i.e., glycophytes, respond to high external salinity by the accumulation of $\mathrm{Na}^{+}$and $\mathrm{Cl}^{-}$(Rush and Epstein 1976; Marschner et al. 1981; Binzel et al. 1988). In other glycophytes, tolerance is apparently associated with enhanced $\mathrm{K}^{+} / \mathrm{Na}^{+}$selectivity, increased $\mathrm{Na}^{+}$ efflux at the plasma membrane, and/or restricted transport of $\mathrm{Na}^{+}$and $\mathrm{Cl}^{-}$, especially to the shoot (Greenway and Munns 1980; Jeschke and Nassery 1981; Jeschke 1984; Walker 1986; Gorham et al. 1987; Yeo and Flowers 1989; Chow et al. 1990; Yang et al. 1990a). The maintenance of relatively lower cytoplasmic concentrations of incompatible ions, e.g., $\mathrm{Na}^{+}$, and adequate concentrations of compatible ions, e.g., $\mathrm{K}^{+}$, emerges as an apparent fundamental property of salt tolerance at the cellular level in some taxa (Leigh and Jones 1984; Ben-Hayyim et al. 1987; Chow et al. 1990). Critical concentration of $\mathrm{K}^{+}$contributes to several important cellular functions, including cytoplasmic and organellar osmotic potential, activation of enzymes in glycolysis, starch synthesis and protein synthesis, maximum photosynthetic activity, control of cytoplasmic $\mathrm{pH}$ and membrane potential, and a correct thermodynamic environment for active form protein folding (Leigh and Jones 1984). Such modifications of $\mathrm{K}^{+}$and $\mathrm{Na}^{+}$contents must result from appropriate $\mathrm{K}^{+}$influx and efflux relative to $\mathrm{Na}^{+}$ fluxes or subcellular partitioning of these ions principally between the cytoplasm and vacuole. However, little is known about the specific physiological mechanisms that can yield these responses.

It is apparent even from this brief summary that ion transport and its regulation play key roles in the salt-tolerant phenotype (Kramer 1984; Flowers and Yeo 1986) and that the tolerance responses of plants to excess salinity involve potentially numerous, extremely complex, and highly integrated responses at the subcellular, cellular, and interorgan and organismal level (Epstein and Rains 1987; Cheeseman 1988; Yeo and Flowers 1989; Claes et al. 1990; Adams et al. 1992). This complexity is not merely a function of the large numbers of potential processes but is also the result of the indirect interactions and complexities associated with such ion transport phenomena themselves (Glass 1989). For instance, alterations in ion transport not only may directly modify intracellular ion contents but also may change the fundamental driving forces for ion transport, i.e., $\Delta \mu_{\mathrm{H}+}$ and $\mathrm{E}_{\mathrm{m}}$. Changes in these membrane gradients, in turn, could immediately influence any number of transport processes driven by or coupled to an electrochemical gradient independent of their involvement with salt tolerance. These alterations, especially in conjunction with any additional genetic differences among strains being compared, could result in an almost indecipherable phenotypic response. In addition, the responses of whole plants reflect the integration of processes operating among the external environment, cell wall, root cells, vascular system, shoot cells, and leaf cells and make the dissection of individual mechanisms exceedingly difficult.

\section{Genetic complexity of salt tolerance}

Because of the unavailability of isogenic lines differing only in salt tolerance, nearly all physiological studies have been restricted to comparisons between different taxa or varieties that likely have significant genetic differences in addition to those differences specifically related to responses to salt stress. Naturally evolved salt tolerance is a quantitative and polygenic trait associated with numerous morphological and biochemical adaptations (Shannon 1984, 1985; Tal 1984, 1985; Epstein and Rains 1987; Cushman et al. 1989). The level of genetic complexity is evidenced by the multigenic inheritance, e.g., various heritabilities, of salt tolerance traits in such taxa as rice (Yeo et al. 1988), barley (Forster et al. 1990), tomato (Saranga et al. 1992), various grass species (Ashraf et al. 1986), pigeonpea (Subbarao et al. 1990), and wheat (Schachtman and Munns 1992). In the Triticaceae, responses to salt of chromosome addition lines from Thinopyrum elongatum into tetraploid (Triticum durum cv Stewart) or hexaploid wheat (Triticum aestivum Chinese Spring) show that several chromosomes may contribute to $\mathrm{Na}^{+}$exclusion, distinct from the $\mathrm{K}^{+} / \mathrm{Na}^{+}$discrimination trait controlled by Knal in the D genome of wheat (Gorham 1994).

The potential for genetic and physiological complexity is also evident in changes in gene expression analyzed by 2-D gel electrophoresis of in vivo labeled proteins and in vitro translation products from mRNA (Bohnert et al. 1989; Cushman et al. 1989; Claes et al. 1990; Hurkman et al. 1991). For instance, salt stress results in quantitative changes in the synthesis of some proteins and may or may not induce unique proteins (Hurkman et al. 1988, 1989; Hurkman 1990). Salt-induced changes in polypeptide and mRNA levels in the roots of sensitive (cv Prato) and tolerant (cv CM72) cultivars of barley (Hordeum vulgare $\mathrm{L}$.) were small and similar (Hurkman et 
al. 1989). Various techniques have identified several proteins such as osmotin (Singh et al. 1985), the rice salT (Claes et al. 1990), and the barley germin-like polypeptide (Hurkman et al. 1991) that are induced or modulated by salt stress. Although these molecular approaches are useful for descriptive analyses of salinity responses, they cannot distinguish between the general effects of salt stress, a salt-induced response that confers tolerance, and/or whether the changes are genetically related to a salt-tolerance trait (Cheeseman 1988; Hurkman 1990).

An alternative approach is needed to identify and effectively resolve the contributing individual physiological mechanisms associated with a salt-tolerant phenotype. One such approach, recognized for a number of years, is the use of strains bearing single gene mutations that confer some level of salinity tolerance. However, even given more than $30 \mathrm{yr}$ of exploration, few well-defined mutants are available. The few mutants that have been studied typically exhibit either greater sensitivity to salt stress or tolerance that is restricted developmentally. For instance, the wilty mutant of pepper (Capsicum annuum, scabrous diminutive) accumulates more $\mathrm{Na}^{+}$and less $\mathrm{K}^{+}$and effluxes less $\mathrm{Na}^{+}$and more $\mathrm{K}^{+}$in $100 \mathrm{mM} \mathrm{NaCl}-$ supplemented medium than the wildtype genotype (Tal and Benzioni 1977; Benzioni and Tal 1978). This wilty mutant is also associated with excessive stomatal opening and possible cuticular changes that result in lower leaf resistance to water loss and alterations in leaf anatomy (Tal et al. 1974). Tal (1985) outlined a possible series of epigenetic events that could account for the pleiotropic effects associated with this wilty mutant and has proposed an unidentified change in "membranal components" as the likely site of the lesion that subsequently influences several transport processes and morphology. Likewise, the $\mathrm{Cl}^{-}$transport mutant of soybean shows enhanced sensitivity to salt stress (Abel 1969). The recently reported salt-tolerant mutants of Arabidopsis thaliana express tolerance only in germination responses and are reportedly based on changes of osmotic relations and an enhanced capacity for seed imbibition under water stress conditions (Saleki et al. 1993).

In addition to traditional breeding approaches and selections based on whole plants, cell and tissue culture selections have been used to isolate salt-tolerant lines. This approach has resulted in the successful establishment of salt-tolerant cell or callus variants for a large number of taxa $(\mathrm{Na}-$ bors et al. 1975; Nabors et al. 1980; Croughan et al. 1981; Tyagi et al. 1981; Kochba et al. 1982; Rangan and Vasil 1983; Smith and McComb 1983; Watad et al. 1983; Chandler and Vasil 1984; Pandey and Ganapathy 1984; Hassan 1988; Winicov 1991; Dix 1993). Although cell and tissue culture approaches provide some advantages over conventional breeding, many difficulties continue to plague this approach (Stavarek et al. 1980; Epstein and Rains 1987; Dracup 1991). Only a few of the salt-tolerant variants have been successfully regenerated as whole plants, which has limited their usefulness in associating specific genetic changes with a salt-tolerant phenotype; and often regenerated plants lack expression of the salt-tolerant trait (Dix et al. 1984; Epstein and Rains 1987).

Currently, substantial information on the genetics of salt-tolerant variants is limited to $\mathrm{Ni}$ cotiana tabacum (Nabors et al. 1980; Bressan et al. 1987), Nicotiana plumbaginifolia (Sumaryati et al. 1992), and alfalfa (Winicov 1991). In alfalfa, salt tolerance was maintained in callus cultures derived from regenerated salt-tolerant plants. The segregation of tolerant and sensitive phenotypes in progeny of selfed regenerated plants indicated a dominant-type inheritance. However, the autopolyploid nature of alfalfa and non-Mendelian segregation ratios precluded a formal genetic interpretation. Sumaryati (Sumaryati et al. 1992) identified individual mutants resistant to $\mathrm{NaCl}$, $\mathrm{KCl}$, and PEG from protoplast-derived colonies of haploid $N$. plumbaginifolia (Vivani). Following regeneration of diploid plants, presumably by spontaneous chromosome doubling, the tolerance trait was inherited in each mutant as a single dominant gene. However, the $\mathrm{NaCl}$ - and $\mathrm{KCl}-$ tolerant mutants were male sterile even after two successive backcrosses with the wildtype. In the most comprehensively studied system, $N$. tabacum var. Wisconsin (W38) cells, stable expression of tolerance in the absence of salt depends on the level of salt used for adaptation (Bressan et al. 1985). In cells adapted to $428 \mathrm{mM} \mathrm{NaCl}$ (S25) the non-Mendelian inheritance of $\mathrm{NaCl}$ survivability and of reduced growth rate, a trait associated with the salt-tolerant phenotype, indicates polygenic and/or cytoplasmic inheritance (Bressan et al. 1987). Inheritance and expression of tolerance and associated traits may be further complicated by polyploid chromosome number changes in the S25 cell line (hexaploid) (Kononowicz et al. 1990a, 1990b).

In addition to these noted genetic complexities, extensive comparative physiological analyses of salt-tolerant $N$. tabacum S25 cells (Binzel et al. 1985) have identified several independent physiological mechanisms that may contribute to the salt-tolerance trait in this cell line, e.g., modified plasma membrane $\mathrm{H}^{+}$-ATPase activity (Reuveni et al. 1993); accumulation of osmotica, including $\mathrm{Na}^{+}, \mathrm{Cl}^{-}$, and organic solutes (Binzel et al. 1987); cytoplasmic volume changes and differential compartmentation of $\mathrm{Na}^{+}$and $\mathrm{Cl}^{-}$to the vacuole (Binzel et al. 1988); more effective $\mathrm{Na}^{+}$exclusion (Binzel et al. 1989); and accumulation of osmotin 


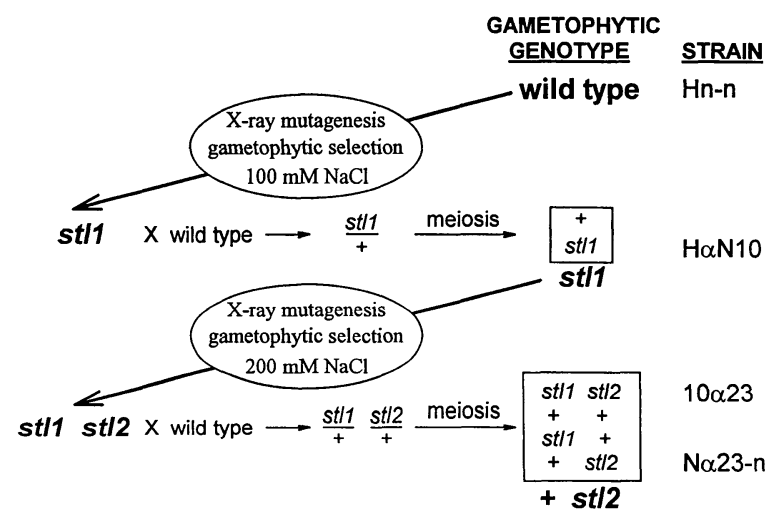

Fig. 1 Selection strategy for modified serial selection procedure and identification and isolation of single gene salttolerant mutants in the homosporous fern Ceratopteris.

I and reduced growth rate (Bressan et al. 1987). The wide diversity of these traits indicates extensive pleiotropy or epigenetic interactions that limit the potential to associate physiological mechanisms with specific genetic changes.

\section{Ceratopteris and salt-tolerant mutants}

Ideally, the physiology of single gene mutations should be studied in a genetic background isogenic to the wildtype to allow for identification of specific physiological processes associated with the salt-tolerance trait. To obtain such single gene mutations requires a system that is capable of rapidly screening very large numbers $\left(>10^{6}\right)$ of individuals, is highly sensitive, and can easily discriminate minor differences in tolerance, is morphologically simple, and, most important, is genetically well defined such that mutants arise in a nearly isogenic background. We have successfully used Ceratopteris to select for single gene mutations that confer salt tolerance to gametophytes. The unique life cycle and genetics of homosporous ferns allow an unlimited population of genetically identical spores to be generated after a single generation of intragametophytic selfing (Hickok 1987; Hickok et al. 1987; Hickok et al. 1995). Such a completely isogenic population of spores is then mutagenized, either by X-irradiation or chemical (EMS) mutagenesis, and cultured on medium supplemented with a selection agent, e.g., $100 \mathrm{mM} \mathrm{NaCl}$ (Warne and Hickok 1987) (fig. 1). Tolerant individuals can be isolated and self-fertilized to generate a completely homozygous M1 sporophyte carrying the putative mutation of interest in a homozygous state. Both dominant and recessive mutants can be recovered in a single generation. Gametophytes derived from M1 spores can be tested to confirm tolerance and crossed to carry out genetic studies. Since selection is carried out in the nonvascular haploid gametophyte, complications associated with the vascular system are avoided. Gameto-

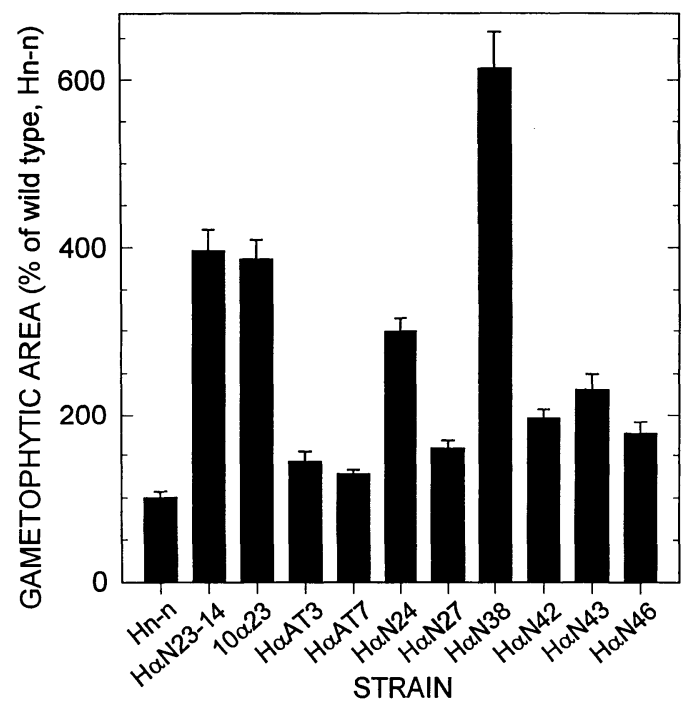

Fig. 2 Gametophytic areas of Ceratopteris strains carrying known salt-tolerant mutations, i.e., stl2 (H $\alpha \mathrm{N} 23-14)$ and stl1 stl2 (10 $\alpha 23)$, various putative mutants that express salt tolerance in $\mathrm{M} 2$ generation gametophytes and the wildtype (Hnn). $\mathrm{H} \alpha \mathrm{Nn}$ represents sister selections of $\mathrm{H} \alpha \mathrm{N} 10$ from a screen on $100 \mathrm{mM} \mathrm{NaCl}$ (fig. 1). $\mathrm{H} \alpha \mathrm{ATn}$ represents selections from aluminum-EDTA screen that are also tolerant to low $\mathrm{pH}$ (Wright et al. 1990). Precordate gametophytes were transferred to medium supplemented with $175 \mathrm{mM} \mathrm{NaCl}$ and cultured for $17 \mathrm{~d}$. Areas of gametophytes stained and mounted in a Hoyer's medium-acetocarmine mixture were measured using a computer-interfaced image analysis system (Bioquant IV). Values represent the mean \pm SE of $n=10$.

phytes are exposed to $\mathrm{NaCl}$ for usually less than $21 \mathrm{~d}$. Individuals that exhibit tolerance are removed from salt, isolated onto salt-free medium, and watered to effect intragametophytic selfing. Only those gametophytes that develop functional gametangia and produce sporophytes are used to generate material for further analyses.

\section{Genetic characterization of salt-tolerant mutants: $s t / 1, s t / 2$, and $s t / 3$}

An original screen of $1.25 \times 10^{6}$ spores on 100 $\mathrm{mM} \mathrm{NaCl}$-supplemented medium resulted in a selection of over 40 individuals that showed wideranging tolerance to $\mathrm{NaCl}$ (Warne and Hickok 1987). A retest of tolerance for several of these selections show that original M1 spores have retained tolerance for over $8 \mathrm{yr}$ in storage (fig. 2). Two of these original selections were characterized genetically as unlinked single nuclear gene mutations; strain $\mathrm{H} \alpha \mathrm{N} 16$, carrying the stl3 mutation, and $\mathrm{H} \alpha \mathrm{N} 10$, which carries the stll mutation (Warne and Hickok 1987). We commonly designate individual selections as separate strains even though they are selected directly from identical populations of mutagenized wildtype spores and can be considered nearly isogenic to each other and the wildtype with the exception of any induced mutation. In addition, once they are defined genetically, we refer to such strains merely 
Table 1

RESPONSE OF THE WILDTYPE, stl1, AND st 2 TO VARIOUS IONIC AND OSMOTIC STRESS AGENTS

\begin{tabular}{cccr} 
& \multicolumn{3}{c}{$\mathrm{I}_{\text {s0 }}(\mathrm{mM})$} \\
\cline { 2 - 4 } \multicolumn{1}{c}{ Treatment } & Wildtype & stl & stl \\
\hline $\mathrm{NaCl} \ldots \ldots \ldots$ & 100 & 110 & 175 \\
$\mathrm{Na}_{2} \mathrm{SO}_{4} \ldots \ldots \ldots$ & 25 & 35 & 120 \\
$\mathrm{MgCl}_{2} \ldots \ldots \ldots$ & 25 & 25 & 80 \\
$\mathrm{MgSO}_{4} \ldots \ldots \ldots$ & 25 & 25 & 100 \\
$\mathrm{KCl}_{4} \ldots \ldots \ldots$ & 50 & 50 & 50 \\
$\mathrm{~K}_{2} \mathrm{SO}_{4} \ldots \ldots \ldots$ & 25 & 25 & 25 \\
Mannitol $\ldots \ldots$ & 225 & 260 & 260 \\
Melibiose $\ldots \ldots$ & 190 & 225 & 280
\end{tabular}

$I_{50}$ is the approximate concentration $(\mathrm{mM})$ that gives $50 \%$ inhibition of gametophytic growth. Values were obtained from dose response curves in Hickok et al. (1991), Vogelien (1993), and Vogelien et al. (1995).

by the salt-tolerance mutation they carry, e.g., stll.

Because spore germination in stl1 under salt stress was substantially higher than the wildtype, we used stll in a subsequent selection at a higher $\mathrm{NaCl}$ concentration $(200 \mathrm{mM})$. From this, we obtained the highly tolerant mutant strain $10 \alpha 23$. Segregation tests subsequently showed that $10 \alpha 23$ carried two unlinked mutations, stll and stl2 (fig. 1; Hickok et al. 1991). The new mutation, stl2, exhibited partial additivity with stll and independently conferred tolerance up to $275 \mathrm{mM}$ $\mathrm{NaCl}$. stl 2 was segregated from stll by backcrossing to the wildtype and was established as a single mutant homozygous $\mathrm{N} \alpha 23-14$ strain. It is highly likely that such strains, which originate from a single haploid gametophyte, bear only a single mutation for the trait in question. The induced mutation rate, based on estimates from selections with lethal concentrations of paraquat and FdUR, is ca. $10^{-5}$. Given this as an estimate of the mutation rate for any given gene, the probability of any spore bearing two mutations that affect the same physiological process would be very small.

These single gene mutations provide the means to identify genetically regulated individual physiological processes that confer $\mathrm{NaCl}$ tolerance. The ability to use this type of discrete serial selection approach coupled with the subsequent isolation of individual mutations can also permit identification of genetic changes that are in themselves phenotypically cryptic but that act in concert to enhance tolerance, as has been done with paraquat tolerance (Hickok and Schwarz 1989). Since haploid gametophytes are essentially a single cell layer thick, only a few square millimeters at maturity, and have relatively limited cellular differentiation, it is likely that mutations conferring tolerance are associated with a cellular-based response. Mutations that confer known tolerance at a cellular level can subsequently be indepen- dently tested and characterized for tolerance in the sporophyte phase of the life cycle (Augé et al. 1989). With this system, given a single gene mutation in a genetic background essentially isogenic to the wildtype, differential responses of the mutant strain compared with its nearly isogenic wildtype will indicate those physiological mechanisms responsible for the salt-tolerant phenotype. This approach is based on the unique genetics of homosporous ferns and serves as a powerful means to examine the individual contributing mechanisms of physiologically complex traits.

\section{Physiological characterization of the salt-tolerant mutants: stll and stl2}

\section{OSMOTIC AND IONIC RESPONSES}

To date, we have undertaken a comparative evaluation of stll, stl2, and the wildtype with regard to a large number of physiological traits commonly associated with salt tolerance, including water relations, accumulation of inorganic (ions) and organic (amino acids, betaine, soluble carbohydrates, malate) solutes, responses to various osmotic and ionic stresses, $\mathrm{K}^{+}, \mathbf{M g}^{2+}$, and $\mathrm{Ca}^{2+}$, as well as $\mathrm{K}^{+}$influx and efflux and electrophysiological responses, in order to identify physiological differences associated with these mutations.

stl1 confers a low level of tolerance to $\mathrm{NaCl}$ and to $\mathrm{Na}_{2} \mathrm{SO}_{4}$, as well as to mannitol and melibiose, yet can be clearly identified both quantitatively and qualitatively in dose response and segregation tests (table 1; Warne and Hickok 1987; Vogelien 1993; Vogelien et al. 1995). stl1, like the wildtype, is sensitive to $\mathrm{Mg}^{2+}$ and $\mathrm{K}^{+}$salts (table 1). In response to $60 \mathrm{mM} \mathrm{NaCl}$, both the wildtype and stll exhibit substantial changes in contents of total amino acids, soluble carbohydrates, malate, and major ions (Vogelien et al. 1993). However, both stl1 and the wildtype are essentially similar in their content of most major ions $\left(\mathrm{K}^{+}, \mathrm{Ca}^{2+}, \mathrm{Mg}^{2+}, \mathrm{Cl}^{-}\right)$and organic solutes (amino acids, betaines, soluble carbohydrates, and malate), both constitutively and in response to long-term exposure $(21 \mathrm{~d})$ to $60 \mathrm{mM} \mathrm{NaCl}$. In addition, there were no substantial differences between stll and the wildtype in osmotic responses (turgor, water, and osmotic potentials) (Vogelien et al. 1993). Supplemented $\mathrm{Ca}^{2+}(1 \mathrm{mM}$ vs. 0.2 $\mathrm{mM}$ ) alleviated growth inhibition to a similar extent in both the wildtype and stll during $\mathrm{NaCl}$ or $\mathrm{MgCl}_{2}$ stress (Vogelien 1993; Vogelien et al. 1995). The enhancement of tolerance to $\mathrm{NaCl}$ by $\mathrm{Ca}^{2+}$ was accompanied by an increased $\mathrm{K}^{+}$and lower $\mathrm{Na}^{+}$content. The only difference of note between the wildtype and stll was the reduced accumulation of $\mathrm{Na}^{+}$in stll (33 mM) compared 
with that of the wildtype ( $47 \mathrm{mM})$ under longterm exposure to $60 \mathrm{mM} \mathrm{NaCl}$ and the associated increased $\mathrm{K}^{+} / \mathrm{Na}^{+}$ratio. With shorter-term exposures $(3 \mathrm{~d})$, stll had reduced $\mathrm{Na}^{+}$content compared with the wildtype only at external concentrations greater than $120 \mathrm{mM}$. The absence of any clearly defined physiological response indicates that tolerance may be associated with a more subtle process, such as a minor increase in selectivity against $\mathrm{Na}^{+}$.

In contrast to stll, the phenotypic suite of characters exhibited by stl 2 indicates a mutation with a complex mechanism of action. stl 2 confers a high level of tolerance not only to $\mathrm{Na}^{+}(\mathrm{NaCl}$, $\left.\mathrm{Na}_{2} \mathrm{SO}_{4}\right)$ but also to $\mathrm{Mg}^{2+}$ salts $\left(\mathrm{MgCl}_{2}, \mathrm{MgSO}_{4}\right)$ (table 1; Hickok et al. 1991; Vogelien 1993; Vogelien et al. 1995). Tolerance to mannitol was equivalent to stll, and higher tolerance than either wildtype or stll was evident with melibiose (table 1). stl2 was not different from stll and the wildtype in osmotic responses and in the contents of organic solutes, $\mathrm{Ca}^{2+}, \mathrm{Mg}^{2+}$, and $\mathrm{Cl}^{-}$, both constitutively and in response to long-term exposure $(21 \mathrm{~d})$ to $60 \mathrm{mM} \mathrm{NaCl}$ (Vogelien et al. 1993).

However, stl 2 exhibited substantial differences from stll and the wildtype in the accumulation of both $\mathrm{K}^{+}$and $\mathrm{Na}^{+}$during long-term exposure to $\mathrm{NaCl}(21 \mathrm{~d})$ (Vogelien et al. 1993). In the presence of $60 \mathrm{mM} \mathrm{NaCl}$, the $\mathrm{K}^{+}$content in stl 2 was nearly twice that of the wildtype ( 99 vs. $55 \mathrm{mM}$ ) and the $\mathrm{Na}^{+}$content was nearly one-half of the wildtype ( 24 vs. $47 \mathrm{mM}$ ). These differences result in a substantially high $\mathrm{K}^{+} / \mathrm{Na}^{+}$ratio in $s t l 2$, i.e., 4.0 compared with 1.1 in the wildtype. stl 2 maintains a higher $\mathrm{K}^{+}$, lower $\mathrm{Na}^{+}$content, and subsequently higher $\mathrm{K}^{+} / \mathrm{Na}^{+}$ratio for concentrations up to at least $175 \mathrm{mM} \mathrm{NaCl}$ during shortterm exposure $(3 \mathrm{~d})$.

Even though supplemental $\mathrm{Ca}^{2+}(0.2$ vs. $1 \mathrm{mM}$ $\mathrm{CaSO}_{4}$ ) did not alleviate growth inhibition by $\mathrm{NaCl}$ (up to $200 \mathrm{mM}$ ) or $\mathrm{MgCl}_{2}$ (up to $100 \mathrm{mM}$ ), it did result in a reduced accumulation of $\mathrm{Na}^{+}$ ( 30 vs. $16 \mathrm{mM}$ ) and an increased accumulation of $\mathrm{K}^{+}(72$ vs. $116 \mathrm{mM})$ in gametophytes grown at $175 \mathrm{mM} \mathrm{NaCl}$ (Vogelien et al. 1995). This response to $\mathrm{Ca}^{2+}$, which was substantially different from that of the wildtype, indicates the possible involvement of this ion in a salt-tolerance response.

stl 2 also differs substantially from both stll and the wildtype in its response to external concentrations of $\mathrm{K}^{+}$(Vogelien 1993; Vogelien et al. 1995). Under standard conditions $\left(3.7 \mathrm{mM} \mathrm{K}^{+}\right)$, growth of stl 2 is only $60 \%$ of the wildtype. Reduction of extracellular $\mathrm{K}^{+}$to trace levels or that present only as a contaminant in the agar resulted in a ca. $40 \%$ increase in growth to a size equivalent with the wildtype under the same conditions. In addition to $\mathrm{K}^{+}$sensitivity, stl 2 main- tained substantially greater tolerance to low $\mathrm{NaCl}$ levels $(75 \mathrm{mM})$ even when $\mathrm{K}^{+}$was at trace levels. Tissue ion content of $\mathrm{K}^{+}$and $\mathrm{Na}^{+}$were similar for $s t l 2$ and the wildtype with different levels of $\mathrm{K}^{+}$supplementation $(0.37$ vs. $3.7 \mathrm{mM})$ in the absence of $\mathrm{NaCl}$. In the presence of $175 \mathrm{mM}$ $\mathrm{NaCl}, 3.7 \mathrm{mM} \mathrm{K}^{+}$resulted in a substantially greater $\mathrm{K}^{+}$and lower $\mathrm{Na}^{+}$content in stl2 compared with the wildtype.

\section{$\mathrm{K}^{+}$INFLUX, EFFLUX, AND ELECTROPHYSIOLOGICAL RESPONSES}

Recent examination of very short term $\mathrm{Rb}^{+}$ influx $(10 \mathrm{~min})$ and efflux $(2 \mathrm{~h})$ and electrical responses have shown substantial differences between $s t l 2$ and the wildtype that are consistent with $\mathrm{K}^{+}$and $\mathrm{Na}^{+}$contents in stl2 both in the presence and absence of $\mathrm{NaCl}$ (long and short term) and the observed growth inhibition of stl2 by $\geq 1 \mathrm{mM} \mathrm{K}^{+}$(Warne et al., unpublished). In these influx experiments, $\mathrm{RbCl}$ completely replaced $\mathrm{KCl}$ so that the direct effects of any putative difference in $\mathrm{K}^{+}$transport between the wildtype and stl 2 could be observed independently of any differential selective effects of $\mathrm{K}^{+}$ over $\mathrm{Rb}^{+} . \mathrm{Rb}^{+}$has been classically and extensively used as a tracer for $\mathrm{K}^{+}$and has been shown to move through $\mathrm{K}^{+}$channels (Bentrup 1990; Tester 1990). Though uptake rates are identical to the wildtype at concentrations less than 0.5 $\mathrm{mM}$ and greater than $50 \mathrm{mM}$, stl2 has substantially higher uptake (ca. $30 \%$ greater) at $0.5-10$ $\mathrm{mM} \mathrm{Rb}$. In addition, $\mathrm{RbCl}(5 \mathrm{mM})$ induced about a twofold times greater membrane depolarization in stl2 than the wildtype. However, the experimental use of $\mathrm{Rb}^{+}$may underestimate the extent of the difference between stl 2 and the wildtype, since $5 \mathrm{mM} \mathrm{KCl}$ resulted in a 2.6-fold greater depolarization in stl2. The greater depolarization by $\mathrm{Rb}^{+}$or $\mathrm{K}^{+}$and enhanced uptake in $s t l 2$ was not the result of different driving forces available for cation uptake since membrane potentials in both the wildtype and stl2 were ca. $-150 \mathrm{mV}$ $(\mathrm{n}=>30)$. In addition to these differences in uptake and electrical responses to $\mathrm{Rb}^{+}$and/or $\mathrm{K}^{+}$, stl2 also exhibits consistently higher $\mathrm{K}^{+}$stimulated secretion of $\mathrm{H}^{+}$(fig. 3).

In the presence of $\mathrm{NaCl}$, differences in $\mathrm{K}^{+}$uptake and electrical responses between $s t l 2$ and the wildtype are maintained. $\mathrm{Na}^{+}$inhibits $\mathrm{Rb}^{+}$uptake in both the wildtype and stl2; however, stl2 retains both higher absolute and normalized uptake of $\mathrm{Rb}^{+}$up to ratios of $0.5 \mathrm{mM} \mathrm{Rb^{+ }}: 180$ $\mathrm{mM} \mathrm{Na}{ }^{+}$. In addition, following treatment with $\mathrm{NaCl}$ (60 and $120 \mathrm{mM}$ ), subsequent depolarization induced by $5 \mathrm{mM} \mathrm{K}^{+}$was greater in stl2.

Unlike $\mathrm{Na}^{+}$, short-term exposure to $\mathrm{Mg}^{2+}$ is not associated with significant inhibition of $\mathrm{Rb}^{+}$ uptake even though chronic exposure to the same concentrations is strongly inhibitory to growth. 
Though $5 \mathrm{mM} \mathrm{Mg} \mathrm{Mg}^{2+}\left(\mathrm{MgCl}_{2}\right)$ inhibited $\mathrm{Rb}^{+}$uptake in stl 2 and the wildtype by about $20 \%$, additional $\mathrm{Mg}^{2+}$, up to $40 \mathrm{mM}$, had little further effect. Since the mechanism(s) of $\mathbf{M g}^{2+}$ toxicity are unknown - for example, whether it is associated with excessive cytoplasmic accumulation or interaction with $\mathrm{Ca}^{2+}$ - the exceptional tolerance by $s t l 2$ to this ion remains enigmatic. Toxicity, as reflected in an alteration of $\mathrm{K}^{+}$influx, may only occur with longer-term exposure to $\mathrm{Mg}^{2+}$. For example, a longer exposure may be necessary for sufficient $\mathrm{Mg}^{2+}$ to accumulate to affect gating properties in $\mathrm{K}^{+}$channels (Matsuda 1988).

Though $\mathrm{Ca}^{2+}$ had a substantial effect on $\mathrm{K}^{+}$ and $\mathrm{Na}^{+}$content of wildtype and stl2 gametophytes grown in $\mathrm{NaCl}$-supplemented medium, in the absence of $\mathrm{NaCl}, \mathrm{Ca}^{2+}$ had no effect on the content of these ions. Likewise, $\mathrm{Ca}^{2+}$ supplementation up to $1.5 \mathrm{mM}$ had no effect on $\mathrm{Rb}^{+}$uptake in either genotype. These responses indicate that $\mathrm{Ca}^{2+}$ may act independently of $\mathrm{K}^{+}$uptake to modulate levels of $\mathrm{Na}^{+}$and $\mathrm{K}^{+}$. $\mathrm{Ca}^{2+}$-induced alterations in $\mathrm{K}^{+}$and $\mathrm{Na}^{+}$contents are sufficient to ameliorate salt stress in the wildtype, but not in stl2.

$\mathrm{Rb}^{+}$influx was also measured in the presence of the quaternary ammonium salt, tetraethylammonium chloride (TEA; $10 \mathrm{mM})$, and $\mathrm{CsCl}(10$ $\mathrm{mM})$. Both of these compounds have been shown to block potassium channels or uptake in the excitable membranes of animal cells, Chara, and corn roots presumably by reversibly occluding the mouth of the pore (Hille 1967; Tester 1988; Bentrup 1990; Jan and Jan 1992). Both the wildtype and stl2 showed similar inhibition of $\mathrm{Rb}^{+}$ influx for TEA (20\%-30\%) and $\mathrm{Cs}^{+}(70 \%-80 \%)$. The reduced effectiveness of TEA as an inhibitor of $\mathrm{K}^{+}$transport has been observed in low-salt roots of corn and other tissue in which TEA fails to accumulate readily (Kochian and Lucas 1988). Since gametophytic tissue was pretreated in a "low-salt"-type medium for up to $6 \mathrm{~h}$ prior to experimental use, it is possible that it responds in a similar TEA-insensitive manner. A dramatic differential response to inhibition of $\mathrm{Rb}^{+}$uptake occurred with exposure to $\mathrm{NH}_{4} \mathrm{Cl}$. $\mathrm{NH}_{4}{ }^{+}$has been shown to inhibit $\mathrm{K}^{+}$influx (Bloom and Finazzo 1986; Vale et al. 1987; Topa and Jackson 1988), cause significant depolarization of membrane potential (Ayling 1993), and pass through $\mathrm{K}^{+}$influx channels (Tester 1990). Inhibition of $\mathrm{Rb}^{+}$influx by $\mathrm{NH}_{4}{ }^{+}$was substantially greater in the wildtype (80\%) compared with stl2 (20\%). Similarly, $\mathrm{NH}_{4}{ }^{+}$ gave a lower depolarization in stl 2 compared with the wildtype, and the capacity for subsequent depolarization by $\mathrm{K}^{+}$was likewise greater in stl2. The current evidence from influx studies using $\mathrm{Rb}^{+}$and the responses to various inhibitors of transport $\left(\mathrm{Na}^{+}, \mathrm{TEA}, \mathrm{Cs}^{+}, \mathrm{NH}_{4}^{+}\right)$as well as elec-

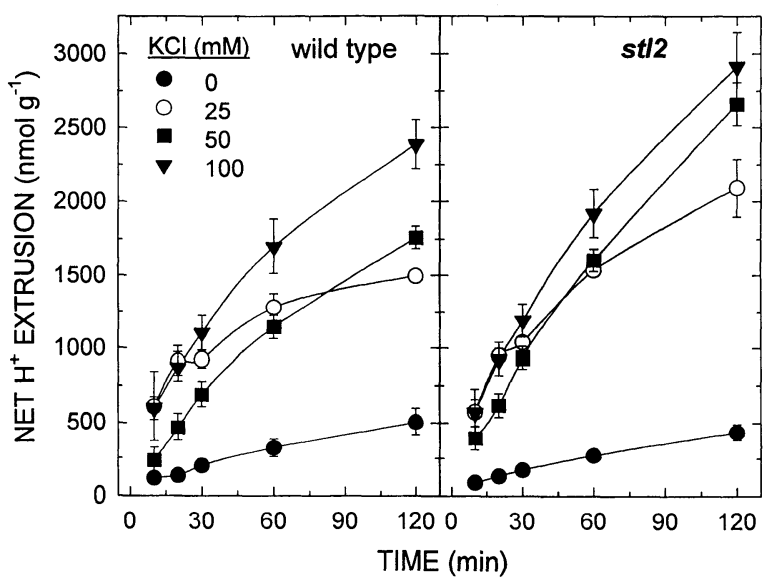

Fig. $3 \mathrm{~K}^{+}$-induced $\mathrm{H}^{+}$secretion in wildtype and $s t l 2$ gametophytes. Fourteen-day-old gametophytes (liquid culture) were rinsed and preincubated in CM buffer $\left(0.5 \mathrm{mM} \mathrm{Ca}_{2} \mathrm{SO}_{4}\right.$, $250 \mu \mathrm{M}$ MES, pH 5.5) for 3-4 $\mathrm{h}$ and then resuspended in fresh buffer and treated with $\mathrm{KCl}$. Aliquots of buffer were removed and $\mathrm{pH}$ was measured using a microelectrode in a flow-through chamber. Standard curves, generated from additions of known amounts of $\mathrm{HCl}(5.00 \mathrm{~N})$ to $\mathrm{CM}$ buffer allowed conversion of measured $\mathrm{pH}$ to quantity of secreted $\mathrm{H}^{+}$. Net $\mathrm{H}^{+}$secreted was calculated by subtracting appropriate controls, i.e., no gametophytes.

trical data are consistent with a modification in velocity and selectivity in a $\mathrm{K}^{+}$influx transport system in stl2. Differences in influx occur only in the concentration range associated with low-affinity $\mathrm{K}^{+}$transport (ca. $>1 \mathrm{mM}$ ) and are absent at those concentrations ascribed with high-affinity uptake (ca. $<1 \mathrm{mM})$. Low-affinity $\mathrm{K}^{+}$influx is generally attributed to inward $\mathrm{K}^{+}$channels (Schroeder and Fang 1991; Gassmann et al. 1993; Kochian and Lucas 1993).

Since constitutive levels of $\mathrm{K}^{+}$in the absence of $\mathrm{NaCl}$ stress are similar in both the wildtype and mutant, i.e., ca. $50 \mathrm{mmol} \mathrm{kg} \mathrm{kg}^{-1}$ plant water, the higher uptake that occurs in stl2 must be associated with a mechanism that can regulate cytoplasmic $\mathrm{K}^{+}$content. For example, such high uptake may be a transient phenomenon that is feedback regulated by increasing cytoplasmic content or coupled with an effective efflux mechanism (Pettersson 1986; Lew 1991). We measured loss of radiolabeled $\mathrm{Rb}^{+}$from gametophytes and into unlabeled rinse medium following a 2-h preloading with $\mathrm{Rb}^{+}$alone. Loss from both genotypes was similar and low when the rinse solution did not contain $\mathrm{K}^{+}$; however, when the rinse solution contained $\mathrm{K}^{+}$at concentrations identical to the $\mathrm{Rb}^{+}$preloading treatment, loss was substantially higher in stl2. $\mathrm{Ca}^{2+}$ has no effect on this $\mathrm{K}^{+}$-dependent $\mathrm{Rb}^{+}$efflux.

\section{Co-segregation analysis is consistent with single gene basis}

Given the complex physiological responses exhibited by stl2, it is important to establish wheth- 


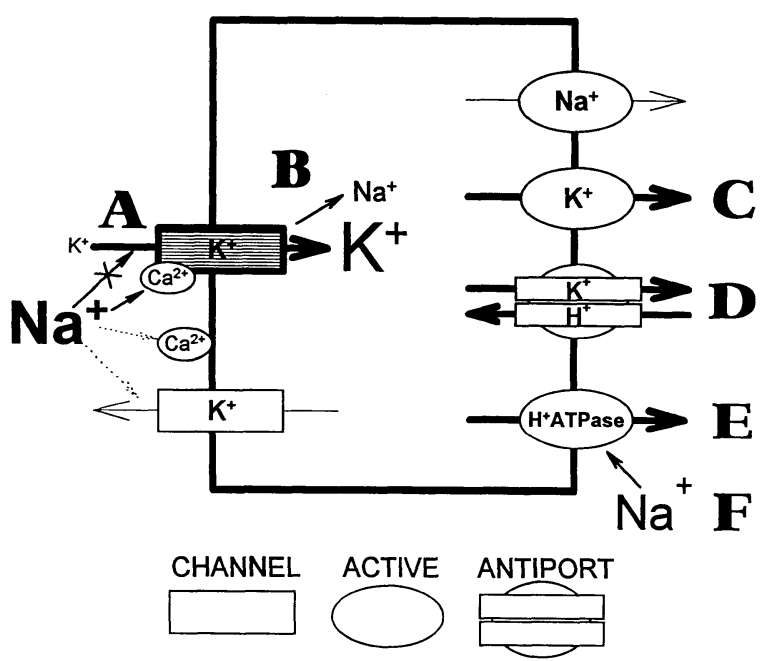

Fig. 4 Proposed model for the mechanism of action of $s t l 2$. An altered $\mathrm{K}^{+}$influx channel $(A)$ possesses a higher selectivity and velocity for $\mathrm{K}^{+}$over $\mathrm{Na}^{+}$such that a greater intracellular $\mathrm{K}^{+} / \mathrm{Na}^{+}$ratio $(B)$ is maintained in the face of $\mathrm{Na}^{+}$stress. In the absence of $\mathrm{Na}^{+}$stress, a constitutive intracellular $\mathrm{K}^{+}$level, similar to that of the wildtype, is maintained by $\mathrm{K}^{+}$efflux mechanisms, e.g., $\mathrm{K}^{+}$pump $(C)$ or $\mathrm{K}^{+} / \mathrm{H}^{+}$antiport $(D)$. Both of these mechanisms directly $(C)$ or indirectly $(D, E)$ use ATP and create an energy debt reflected in growth inhibition that can be alleviated by reduction of extracellular $\mathrm{K}^{+}$or by the interaction of other cations, e.g., $\mathrm{Na}^{+}$, that reduce $\mathrm{K}^{+}$ uptake. In the face of $\mathrm{Na}^{+}$stress, the intracellular content of $\mathrm{K}^{+}+\mathrm{Na}^{+}$increases as a consequence of direct or indirect (osmotic) stimulation of $\mathrm{H}^{+}$-ATPase $(F)$ and subsequent decrease in the membrane potential $\left(\mathrm{E}_{\mathrm{m}}\right)$.

er all these phenotypes, in fact, are a consequence of a single mechanism. We tested for co-segregation of $\mathrm{K}^{+}$sensitivity and salt tolerance in gametophytes from stl2-type, F2 individuals that segregated from a hybrid between the wildtype and strain $10 \alpha 23$, which carries stll and stl 2 (fig. 1). These individuals represent sister strains to $\mathrm{N} \alpha 23-14$, which is the stl2-carrying strain used in all the above studies, and are designated $\mathrm{N} \alpha 23-$ $\mathrm{n}$, where $\mathrm{n}=1,3,4,9,10$, and 16 . Precordate gametophytes from each strain were transferred to control medium $\left(3.7 \mathrm{mM} \mathrm{K}^{+}\right)$, to medium supplemented with $200 \mathrm{mM} \mathrm{NaCl}$, and to medium without added $\mathrm{K}^{+}$, i.e., trace $\mathrm{K}^{+}$. All strains examined exhibit co-segregation of stl2-type salt tolerance (Hickok et al. 1991) and $\mathrm{K}^{+}$sensitivity (Vogelien et al. 1995). These data along with the genetic origin of the mutation in a completely homozygous line and subsequent genetic analyses lend further support for a single gene basis for the salt-tolerant phenotype and corresponding ion transport phenomena.

\section{Model for mechanism of action of st/2}

Given a discrete and single gene basis for the salt-tolerant phenotype of stl2, the above data derived from several different approaches pro- vides compelling evidence for a physiological mechanism of action based upon the operation of an altered $\mathrm{K}^{+}$influx channel at the plasma membrane (fig. 4). In this model, all phenotypic responses are regarded as a direct or indirect consequence of the activity of a modified $\mathrm{K}^{+}$influx channel that has a higher effective velocity of transport and exhibits increased selectivity of $\mathrm{K}^{+}$ relative to $\mathrm{Na}^{+}$and other competing cations, such as $\mathrm{NH}_{4}^{+}$. In the absence of $\mathrm{NaCl}$ stress, the higher $\mathrm{K}^{+}$uptake does not result in a substantial net increase in cytoplasmic $\mathrm{K}^{+}$content, since local increases in $\mathrm{K}^{+}$could promote efflux by a $\mathrm{K}^{+} /$ $\mathrm{H}^{+}$antiport or by an outward $\mathrm{K}^{+}$pump. These efflux mechanisms ultimately utilize ATP either directly or indirectly by the action of a $\mathrm{H}^{+}$-ATPase and result in ATP consumption that is reflected in growth sensitivity to $\mathrm{K}^{+}$. Alleviation of this sensitivity occurs when the external $\mathrm{K}^{+}$ concentration is reduced to near trace levels or by the addition of small amounts of other cations, such as $\mathrm{Na}^{+}$(Hickok et al. 1991). In this case, $\mathrm{Na}^{+}$may interfere with high-velocity $\mathrm{K}^{+}$influx and reduce it to levels more comparable with the wildtype. In the presence of salt stress, the altered selectivity of this channel promotes $\mathrm{K}^{+}$uptake relative to $\mathrm{Na}^{+}$. Since $\mathrm{Na}^{+}$uptake is relatively reduced, those mechanisms responsible for efflux of $\mathrm{Na}^{+}$in the cytoplasm are not swamped and remain relatively more effective in reducing cytoplasmic $\mathrm{Na}^{+}$(Jeschke 1984; Braun et al. 1988). Thus, stl2 can maintain a higher $\mathrm{K}^{+} / \mathrm{Na}^{+}$ratio. As external salt stress increases, the total intracellular cation content, dominated by $\mathrm{K}^{+}$and $\mathrm{Na}^{+}$, in both wildtype and stl 2 increases similarly (Vogelien 1993; Vogelien et al. 1995). Such an increase may result from a stimulation of $\mathrm{H}^{+}$ATPase activity directly by external $\mathrm{Na}^{+}$or in response to a general decrease in water potential (Reinhold et al. 1984; Sze 1985; Reuveni et al. 1987). Over a longer-term exposure to $\mathrm{Na}^{+}$, promotion of higher $\mathrm{H}^{+}$-ATPase activity would result in a lower membrane potential and a greater capacity for cation accumulation. In the face of these changes, stl 2 continues to maintain its higher $\mathrm{K}^{+} / \mathrm{Na}^{+}$ratio, whereas the wildtype accumulates these cations in a lower ratio that is presumably more toxic.

Unique single gene mutations, such as $s t l 2$, provide an unparalleled opportunity to study salt tolerance and to explore in further detail the metabolism and physiology of $\mathrm{K}^{+}, \mathrm{Na}^{+}$, and other ions. The complex phenotypic response observed in stl2 has important implications for studies of salt tolerance, especially those associated with ion transport. If such richly complex phenotypes are generated in single gene mutations arising in a nearly isogenic background, interpretations of tolerance mechanisms based upon comparative 
studies of genetically different salt-tolerant and sensitive taxa must necessarily be highly compromised. Analyses of such mutants, first singly and then in combination, can further our understanding of individual physiological traits that contribute to salt tolerance and ion metabolism as well as afford the means to examine their complex interactions.

\section{Acknowledgments}

This work was supported by the National Research Initiative Competitive Grant Program/ USDA grant 92-37100-7673. We thank Drs. Thomas Kinraide, John Cook, and Melinda Hauser for discussion and assistance as well as an anonymous reviewer for valuable comments.

\section{Literature cited}

Abel GH 1969 Inheritance of the capacity for chloride inclusion and chloride exclusion by soybeans. Crop Sci 9:697698.

Adams P, JC Thomas, DM Vernon, HJ Bohnert, RG Jensen 1992 Distinct cellular and organismic responses to salt stress. Plant Cell Physiol 33:1215-1223.

Ashraf M, T McNeilly, AD Bradshaw 1986 Heritability of $\mathrm{NaCl}$ tolerance at the seedling stage in seven grass species. Euphytica 35:935-940.

Augé RM, LG Hickok, A Stodola 1989 Psychrometric pressure-volume analysis of osmoregulation in roots, shoots and whole sporophytes of salinized Ceratopteris. Plant Physiol 91:322-330.

Ayling SM 1993 The effect of ammonium ions on membrane potential and anion flux in roots of barley and tomato. Plant Cell Environ 16:297-303.

Ben-Hayyim G, U Kafkafl, R Ganmore-Neumann 1987 Role of internal potassium in maintaining growth of cultured Citrus cells on increasing $\mathrm{NaCl}$ and $\mathrm{CaCl}_{2}$ concentrations. Plant Physiol 85:434-439.

Bentrup F-W 1990 Potassium ion channels in the plasmalemma. Physiol Plant 79:705-711.

Benzioni A, M Tal 1978 Ion imbalance in Capsicum scabrous diminutive, a wilty mutant of pepper. II. Rubidium flux. J Exp Bot 29:879-884.

Binzel M, P Hasegawa, A Handa, R Bressan 1985 Adaptation of tobacco cells to $\mathrm{NaCl}$. Plant Physiol 89:118-125.

Binzel ML, PM Hasegawa, D Rhodes, S Handa, AK Handa, RA Bressan 1987 Solute accumulation in tobacco cells adapted to $\mathrm{NaCl}$. Plant Physiol 84:1408-1415.

Binzel ML, FD Hess, RA Bressan, PM Hasegawa 1988 Intracellular compartmentation of ions in salt adapted tobacco cells. Plant Physiol 86:607-614.

1989 Mechanisms of adaptation to salinity in cultured glycophyte cells. Pages 139-157 in JH Cherry, ed. Environmental stress in plants. Springer-Verlag, Berlin.

Blits KC, JL Gallagher 1990 Salinity tolerance of Kosteletzkya virginica. 2. Root growth, lipid content, ion and water relations. Plant Cell Environ 13:419-425.

Bloom AJ, J Finazzo 1986 The influence of ammonium and chloride on potassium and nitrate absorption by barley roots depends on time of exposure and cultivar. Plant Physiol 81:67-69.

Bohnert HJ, JA Olstrem, JM Schmitt 1989 Changes in gene expression elicited by salt stress in Mesembryanthemum crystallinum. Pages 159-171 in JH Cherry, ed. Environmental stress in plants. NATO ASI Series, vol G19. Springer-Verlag, Berlin.

Braun Y, M Hassidim, HR Lerner, L Reinhold 1988 Evidence for a $\mathrm{Na}^{+} / \mathrm{H}^{+}$antiporter in membrane vesicles isolated from roots of the halophyte Atriplex nummularia. Plant Physiol 87:104-108.

Bressan RA, NK Singh, AK Handa, A Kononowicz, PM Hasegawa 1985 Stable and unstable tolerance to $\mathrm{NaCl}$ in cultured tobacco cells. Pages 755-769 in M. Freeling, ed. Plant genetics. Liss, New York.

Bressan RA, NK Singh, AK Handa, R Mount, J Clithero, PM Hasegawa 1987 Stability of altered genetic expression in cultured plant cells adapted to salt. Pages 41-57 in L Monti, E Porceddre, eds. Drought resistance in plants: physiological and genetic aspects. Commission of the European Communities, Brussels.

Chandler S, I Vasil 1984 Selection and characterization of $\mathrm{NaCl}$ tolerant cells from embryogenic cultures of Pennisetum purpureum Schum. (Napier Grass). Plant Sci Lett 37: 157-164.

Cheeseman JM 1988 Mechanisms of salinity tolerance in plants. Plant Physiol 87:547-550.

Cheeseman JM, LK Wilkens 1986 Control of $\mathrm{Na}^{+}$and $\mathrm{K}^{+}$ transport in Spergularia marina. III. Relationship between ion uptake and growth at moderate salinity. Physiol Plant 67:15-22.

Chow WS, MC Ball, JM Anderson 1990 Growth and photosynthetic responses of spinach to salinity: implications of $\mathrm{K}^{+}$nutrition for salt tolerance. Aust J Plant Physiol 17: 563-578.

Claes B, R Dekeyser, R Villarroel, M Van den Bulcke, G Bauw, M Van Montagu, A Caplan 1990 Characterization of a rice gene showing organ-specific expression in response to salt stress and drought. Plant Cell 2:19-27.

Croughan TP, SJ Stavarek, DW Rains 1981 In vitro development of salt resistant plants. Environ Exp Bot 21:317324.

Cushman S, E DeRocher, H Bonhert 1989 Gene expression during adaptation to salt stress. Pages 173-203 in F Katterman, ed. Environmental injury to plants. Academic Press, New York.

Dix PJ 1993 The role of mutant cell lines in studies on environmental stress tolerance: an assessment. Plant J 3: 309-313.

Dix PJ, UA McLysaght, RS Pearce 1984 The potential of cell cultures for the production of salt tolerant cultivars. Pages 219-223 in W Lange, AC Zeven, NG Hogenboom, eds. Efficiency in plant breeding. Pudoc, Wageningen.

Dracup M 1991 Increasing salt tolerance of plants through cell culture requires greater understanding of tolerance mechanisms. Aust J Plant Physiol 18:1-15.

Epstein E, JD Norlyn, DW Rush, RW Kingsbury, DB Kelly, GA Cunninham, AF Wrona 1980 Saline culture of crops: a genetic approach. Science 210:399-404.

Epstein E, DW Rains 1987 Advances in salt tolerance. Plant Soil 99:17-29.

Flowers TJ 1985 Physiology of halophytes. Plant Soil 89: 41-56.

Flowers TJ, SA Flowers, MA Hajibagheri, AR Yeo 1990 Salt tolerance in the halophytic wild rice, Porteresia coarctata Tateoka. New Phytol 114:675-684.

Flowers TJ, PF Troke, AR Yeo 1977 The mechanism of salt tolerance in halophytes. Annu Rev Plant Physiol 28: 89-121.

Flowers T, A Yeo 1986 Ion relations of plants under drought and salinity. Aust J Plant Physiol 13:75-91.

Forster BP, MS Phillips, TE Miller, E Baird, W Powell 1990 Chromosomal location of genes controlling tolerance to salt $(\mathrm{NaCl})$ and vigour in Hordeum vulgare and $H$. chiliense. Heredity 65:99-107. 
Gassmann W, JM Ward, JI Schroeder 1993 Physiological roles of inward-rectifying $\mathrm{K}^{+}$channels. Plant Cell 11:14911493.

Glass ADM 1989 Physiological mechanisms involved with genotypic differences in ion absorption and utilization. HortScience 24:559-564.

Gorham J 1994 Salt tolerance in the Triticaceae: K/Na discrimination in some perennial wheatgrasses and their amphiploids with wheat. J Exp Bot 45:441-447.

Gorham J, C Hardy, RGW Jones, LR Joppa, CN Law 1987 Chromosomal location of $\mathrm{K} / \mathrm{Na}$ discrimination character in the D genome of wheat. Theor Appl Genet 74:584-588.

Greenway H, R Munns 1980 Mechanisms of salt tolerance in nonhalophytes. Annu Rev Plant Physiol 31:149-190.

Hassan NS 1988 In vitro selection for salt tolerant lines in Lycopersicon peruvianum. Plant Cell Rep 7:463-466.

Hickok LG 1987 Applications of in vitro selection systems: whole plant selection using the haploid phase of the fern Ceratopteris. Pages 53-65 in HM LeBaron, RO Mumma, RC Honeycutt, JH Duesing, eds. Biotechnology in agricultural chemistry. American Chemical Society Symposium Series 334, American Chemical Society, Washington, D.C.

Hickok LG, OJ Schwarz 1989 Genetic characterization of a mutation that enhances paraquat tolerance in the fern Ceratopteris richardii. Theor Appl Genet 77:200-204.

Hickok LG, DL Vogelien, TR Warne 1991 Selection of a mutation conferring high $\mathrm{NaCl}$ tolerance to gametophytes of Ceratopteris. Theor Appl Genet 81:293-300.

Hickok LG, TR Warne, RS Fribourg 1995 The biology of the fern Ceratopteris and its use as a model system. Int $\mathbf{J}$ Plant Sci 156:332-345.

Hickok LG, TR Warne, MK Slocum 1987 Ceratopteris richardii: applications for experimental plant biology. Am J Bot 74:1304-1316.

Hille B 1967 The selective inhibition of delayed potassium currents in nerve by tetraethylammonium ion. J Gen Physiol 50:1287-1302.

Hirayama O, M Mihara 1987 Characterization of membrane lipids of higher plants different in salt-tolerance. Agric Biol Chem 51:3215-3221.

Hurkman WJ 1990 Use of two-dimensional gel electrophoresis to characterize changes in gene expression associated with salt stress of barley. Pages 205-225 in F Katterman, ed. Environmental injury to plants. Academic Press, New York.

Hurkman WJ, CS Fornari, CK Tanaka 1989 A comparison of the effect of salt on polypeptides and translatable mRNAs in roots of a salt-tolerant and a salt-sensitive cultivar of barley. Plant Physiol 90:1444-1456.

Hurkman WJ, CK Tanaka, FM DuPont 1988 The effects of salt stress on polypeptides in membrane fractions from barley root. Plant Physiol 88:1263-1273.

Hurkman WJ, HP Tao, CK Tanaka 1991 Germin-like polypeptides increase in barley roots during salt stress. Plant Physiol 97:366-374.

Jan LY, YN Jan 1992 Structural elements involved in specific $\mathrm{K}^{+}$channel functions. Annu Rev Physiol 54:537-555.

Jeschke WK $1984 \mathrm{~K}^{+}-\mathrm{Na}^{+}$exchanges at cellular membranes, intercellular compartmentation of cations, and salt tolerance. Pages 37-66 in RC Staples, GH Toenniessen, eds. Salinity tolerance in plants: strategies for crop improvement. Wiley, New York.

Jeschke WD, H Nassery $1981 \mathrm{~K}^{+}-\mathrm{Na}^{+}$selectivity in roots of Triticum, Helianthus and Allium. Physiol Plant 52:217224.

Jones RGW, R Storey 1981 Betaines. Pages 172-204 in LG Paleg, D Aspinall, eds. Physiology and biochemistry of drought resistance in plants. Academic Press, Sydney.

Kochba J, G Ben-Hayyim, P Spiegel-Roy, S Saad, H Neumann 1982 Selection of stable salt-tolerant callus cell lines and embryos in Citrus sinensis and C. aurantium. Z Pflanzenphysiol 106:111-118.
Kochian LV, WJ Lucas 1988 Potassium transport in roots. Adv Bot Res 15:93-178.

721.

Kononowicz AK, K Floryanowicz-Czekalska, J Clithero, A Meyers, PM Hasegawa, RA Bressan 1990 a Chromosome number and DNA content of tobaccor cells adapted to $\mathrm{NaCl}$. Plant Cell Rep 8:672-675.

Kononowicz AK, PM Hasegawa, RA Bressan $1990 b$ Chromosome number and nuclear DNA content of plants regenerated from salt adapted plant cells. Plant Cell Rep 8:676679.

Kramer D 1984 Cytological aspects of salt tolerance in higher plants. Pages 3-15 in RC Staples, GH Toenniessen, eds. Salinity tolerance in plants: strategies for crop improvement. Wiley, New York.

Kuiper PJC 1984 The response of plant cell membranes to salinity and low temperature. Pages 231-245 in AM Boudet, G Alibert, G Marigo, PJ Lea, eds. Membranes and compartmentation in the regulation of plant functions. Annual Proceedings of the Phytochemical Society of Europe, 24. Clarendon, Oxford.

1985 Environmental changes and lipid metabolism of higher plants. Physiol Plant 64:118-122.

Leigh RA, RGW Jones 1984 A hypothesis relating critical potassium concentrations for growth to the distribution and function of this ion in the plant cell. New Phytol 97:1-13.

Lew RR 1991 Substrate regulation of single potassium and chloride ion channels in Arabidopsis plasma membrane. Plant Physiol 95:642-647.

Marschner H, A Kylin, J Kuiper 1981 Differences in salt tolerance of three sugar beet genotypes. Physiol Plant 51: 234-238.

Matsuda H 1988 Open-state substructure of inwardly rectifying potassium channels revealed by magnesium block in guinea-pig heart cells. J Physiol 397:237-258.

Motah T, J Watanabe, E Takahashi 1987 Sodium, potassium, chloride, and betaine concentrations in isolated vacuoles from salt-grown Atriplex gonelini leaves. Plant Physiol 84:173-177.

Munns R 1993 Physiological processes limiting plant growth in saline soils: some dogmas and hypotheses. Plant Cell Environ 16:15-24.

Nabors M, S Gibbs, C Bernstein, M Meis 1980 NaCl-tolerant tobacco plants from cultured cells. Z Pflanzenphysio 97:13-17.

Nabors MW, A Daniels, L Nadolny, C Brown 1975 Sodium chloride tolerant lines of tobacco cells. Plant Sci Lett 4:155159.

Pandey R, PS Ganapathy 1984 Isolation of sodium chloridetolerant callus line of Cicer arietinum L. cv. BG-203. Plant Cell Rep 3:45-47.

Peeler TC, MB Stephenson, KJ Einspahr, GA Thompson Jr 1989 Lipid characterization of an enriched plasma membrane fraction of Dunaliella salina grown in media of varying salinity. Plant Physiol 89:970-976.

Pettersson S 1986 Growth, contents of $\mathrm{K}^{+}$and kinetics of $\mathrm{K}^{+}\left({ }^{86} \mathrm{Rb}\right)$ uptake in barley cultured at different low supply rates of potassium. Physiol Plant 66:122-128.

Rains DW 1972 Salt transport by plants in relation to salinity. Annu Rev Plant Physiol 23:367-388.

1987 Salinity stress-energy cost of plant cells exposed to salinity. Pages 91-93 in DW Newman, KG Wilson, eds. Models in plant physiology and biochemistry, vol 3. CRC, Boca Raton, Fla.

Rangan TS, IK Vasil 1983 Sodium chloride tolerant embryogenic cell lines of Pennisetum americanum (L.) K. Schum. Ann Bot 52:59-64.

Reinhold L, A Seiden, M Volokita 1984 Is modulation of the rate of proton pumping a key event in osmoregulation? Plant Physiol 75:846-849.

Reuveni M, RA Bressan, PM Hasegawa 1993 Modification of proton transport kinetics of the plasma membrane $\mathrm{H}^{+}$. 
ATPase after adaptation of tobacco cells to $\mathrm{NaCl}$. J Plant Physiol 142:312-318.

Reuveni M, R Colombo, HR Lerner, A Pradet, A PoljakoffMayber 1987 Osmotically induced proton extrusion from carrot cells in suspension culture. Plant Physiol 85:383388.

Rhodes D, S Handa, R Bressan 1986 Metabolic changes associated with adaptation of plant cells to water stress. Plant Physiol 82:890-903.

Rush DW, E Epstein 1976 Genotypic responses to salinity. Differences between salt-sensitive and salt-tolerant genotypes of the tomato. Plant Physiol 57:162-166.

Saleki R, PG Young, DD Lefebvre 1993 Mutants of Arabidopsis thaliana capable of germination under saline conditions. Plant Physiol 101:839-845.

Saranga Y, A Cahaner, D Zamir, A Marani, J Rudich 1992 Breeding tomatoes for salt tolerance-inheritance of salt tolerance and related traits in interspecific populations. Theor Appl Genet 84:390-396.

Schachtman DP, R Munns 1992 Sodium accumulation in leaves of Triticum species that differ in salt tolerance. Aust J Plant Physiol 19:331-340.

Schroeder JI, HH Fang 1991 Inward-rectifying $\mathrm{K}^{+}$channels in guard cells provide a mechanism for low-affinity $\mathrm{K}^{+}$ uptake. Proc Natl Acad Sci USA 88:11583-11587.

Shannon MC 1984 Breeding, selection, and the genetics of salt tolerance. Pages 231-254 in RC Staples, GH Toenniessen, eds. Salinity tolerance in plants: strategies for crop improvement. Wiley, New York.

- 1985 Principles and strategies in breeding for higher salt tolerance. Plant Soil 89:227-241.

Singh NK, AK Handa, PM Hasegawa, RA Bressan 1985 Proteins associated with adaptation of cultured tobacco cells to $\mathrm{NaCl}$. Plant Physiol 79:126-137.

Smith MK, JA McComb 1983 Selection for $\mathrm{NaCl}$ tolerance in cell cultures of Medicago sativa and recovery of plants from a NaCl-tolerant cell line. Plant Cell Rep 2:126-128.

Stavarek SJ, TP Croughan, DW Rains 1980 Regeneration of plants from long-term cultures of alfalfa cells. Plant Sci Lett 19:253-261.

Subbarao GV, C Johansen, JVDK Kumar-Rao, MK Jana 1990 Salinity tolerance in F1 hybrids of pigeonpea and a tolerant wild relative. Crop Sci 30:785-788.

Sumaryati S, I Negrutiu, M Jacobs 1992 Characterization and regeneration of salt- and water-stress mutants from protoplast culture of Nicotiana plumbaginifolia (Viviani). Theor Appl Genet 83:613-619.

Sze $\mathrm{H} 1985 \mathrm{H}^{+}$-translocating ATPases: advances using membrane vesicles. Annu Rev Plant Physiol 36:175-208.

Tal M 1984 Physiological genetics of salt resistance in higher plants: studies on the level of the whole plant and isolated organs. Pages 301-320 in RC Staples, GH Toenniessen, eds. Salinity tolerance in plants: strategies for crop improvement. Wiley, New York.

1985 Genetics of salt tolerance in higher plants: theoretical and practical considerations. Plant Soil 89:199226.

Tal M, A Benzioni 1977 Ion imbalance in Capsicum annuum, scabrous diminutive, a wilty mutant of pepper. I Sodium fluxes. J Exp Bot 28:1337-1341.

Tal M, A Witztum, C Shifriss 1974 Abnormal stomatal behavior and leaf anatomy in Capsicum annuum, scabrous diminutive, a wilty mutant of pepper. Ann Bot 38:983-988.

Tester M 1988 Pharmacology of $\mathrm{K}^{+}$channels in the plasmalemma of the green alga Chara coralina. J Membr Biol 103:159-169.

1990 Plant ion channels: whole-cell and single-channel studies. New Phytol 114:305-340.

Topa MA, WA Jackson 1988 Influence of ambient ammonium on net potassium uptake by decapitated maize seedlings. New Phytol 110:135-141.

Tyagi AK, A Rashid, SC Maheshwari 1981 Sodium chloride resistant cell line from haploid Datura innoxia Mill.: a resistance trait carried from cell to plantlet and vice versa in vitro. Protoplasma 105:327-332.

Vale FR, WA Jackson, RJ Volk 1987 Potassium influx into maize root systems: influence of root potassium concentration and ambient ammonium. Plant Physiol 84:14161420.

Vogelien DL 1993 Physiological characterization of $\mathrm{NaCl}-$ tolerant mutants from Ceratopteris richardii. $\mathrm{PhD}$ diss. University of Tennessee, Knoxville.

Vogelien DL, LG Hickok, RM Augé, AJ Stodola, D Hendrix 1993 Solute analysis and water relations of gametophyte mutants tolerant to $\mathrm{NaCl}$ in the fern Ceratopteris richardii. Plant Cell Environ 16:959-966.

Vogelien DL, LG Hickok, TR Warne 1995 Differential effects of $\mathrm{Na}^{+}, \mathrm{Mg}^{2+}, \mathrm{K}^{+}, \mathrm{Ca}^{2+}$ and osmotic stress on the wild type and $\mathrm{NaCl}$-tolerant mutants, stll and stl2, of Ceratopteris richardii. Plant Cell Environ (in press).

Walker RR 1986 Sodium exclusion and potassium-sodium selectivity in salt-treated trifoliate orange (Poncirus trifoliata) and cleopatra mandarin (Citrus reticulata). Aust J Plant Physiol 13:293-303.

Warne TR, LG Hickok 1987 Single gene mutants tolerant to $\mathrm{NaCl}$ in the fern Ceratopteris richardii: characterization and genetic analysis. Plant Sci 52:49-55.

Watad A-EA, L Reinhold, HR Lerner 1983 Comparison between a stable $\mathrm{NaCl}$-selected Nicotiana cell line and the wild type. Plant Physiol 73:624-629.

Winicov I 1991 Characterization of salt tolerant alfalfa (Medicago sativa L.) plants regenerated from salt tolerant cell lines. Plant Cell Rep 10:561-564.

Wright SR, LG Hickok, TR Warne 1990 Characterization of mutants of Ceratopteris richardii selected on aluminum $\left(\mathrm{Al}_{2}\left(\mathrm{SO}_{4}\right)_{3}-\mathrm{Na}_{2}\right.$ EDTA). Plant Sci 68:257-262.

Yang YW, RJ Newton, FR Miller $1990 a$ Salinity tolerance in Sorghum. I. Whole plant response to sodium chloride in S. bicolor and S. halepense. Crop Sci 30:775-781.

$1990 b$ Salinity tolerance in Sorghum. II. Cell culture response to sodium chloride in $S$. bicolor and $S$. halepense. Crop Sci 30:781-785.

Yeo A 1983 Salinity resistance: physiologies and prices. Physiol Plant 58:214-222.

Yeo AR, TJ Flowers 1989 Selection for physiological characters-examples from breeding for salt tolerance. Pages 217-234 in H Jones, T Flowers, M Jones, eds. Plants under stress. Cambridge University Press, Cambridge.

Yeo AR, ME Yeo, TJ Flowers 1988 Selection of lines with high and low sodium transport from within varieties of an inbreeding species, rice (Oryza sativa). New Phytol 110:1319. 